\title{
Minerals as Essential Raw Materials
}

\author{
By George Otis Smith \\ Director, United States Geological Survey
}

$\mathrm{A}^{\mathrm{n}}$ MERICAN industry must now meet world-wide competition not only in marketing its product, but in procuring its raw material. To the manufacturer, the problem of getting raw material is one of both supply and cost; he must study sources of raw material with a regard for adequacy and permanence as well as for price. He must plan for the future if his large plant is to continue to serve its complex constituency.

Though we have come to appreciate the size of our mineral industry and to recognize its essential relation to other industries, this idea is by no means new; Washington and Jefferson foresaw the raw-material problem and looked westward for new sources of minerals with which to strengthen the growth of the young nation. It happens, too, that the last public utterance of Iincoln was a message given to Schuyler Colfax on the morning of April 14, 1865, to carry to the miners of the west. "I have very large ideas of the mineral wealth of our nation-its development has scarcely commenced. Tell the miners for me that I shall promote their interests to the utmost, because their prosperity is the prosperity of the nation and we shall know in a very few years that we are indeed the treasury of the world."

America's Industrial Dependence upon Mineral Raw Materials

To us, these words of the WarPresident sound prophetic, and indeed it required another great war to force home to America a full understanding of its industrial dependence upon mineral raw materials. The U-boat threat taught us that certain minerals, even the names of which were unfamiliar to most citizens, were in fact "key" commodities without which basic industries could not operate. Domestic independence in these minerals was the necessity that gave birth to substitutes or called into being new sources of supply.

With the gradual approach of normal conditions of world commerce, however, there has been that return to old ways of thinking that might be expected. There must be some economic limit to this possible self-sufficiency even in a country so wealthy in raw materials as our own. With the question of adequate supply, which was uppermost during the war, is now joined the question of satisfactory price, which regains its old-time prominence with the return of competitive conditions; yet the pendulum of economic thought cannot swing back to its former extreme. The truths learned during the war exercise a drag that ought to keep our thinking somewhat nearer the normal.

\section{Quantity Versus Cost of Mineral Raw Materials}

The first lesson learned in the experience of meeting the insistent demands of a war program, with its rapidly expanding industries, was to think in terms of quantity of commod- 
ity rather than its cost. So while we can no longer afford to pay any price for immediate delivery we realize better that quantity is the truer measure of usefulness and that the totals stated in dollars may not express the advances in industrial growth they seem to show. We have lost some of our old-time faith in the dollaras a standard measure.

Connected with this emphasis upon tons rather than dollars in considering the mineral raw materials is the necessity of thinking in terms of low costs rather than in terms of high prices. The day of excess profits that came through over-high prices ought soon to pass and the day of lower levels of both cost and price ought soon to dawn. The producer of raw materials, whether farmer or miner, surely deserves his share, but in discussing profits to owner or wages to worker the truth should never be overlooked that the market price of the mineral fuel or of the ore is but the starting point of some other industry, and only disaster can result from keeping a price too high. The rôle of the mineral industry is not to exploit markets but to supply consumers.

Industrial expansion on the scale imposed upon our country as its part in the war also cleared our judgment as to value in terms of utility. Gold was not one of the "war minerals," the increased output of which then engaged the best efforts of geologist, metallurgist and mine worker. Gold may have had its place in the war chests of militaristic nations and continues to hold its place as the universal measure of value, but gold is not a raw material whose general utility is at all on the scale of its more democratic fellows, like iron or copper. Indeed, there is some reason to liken this noble metal, gold, which has so long held the allegiance of mankind, to the idle aristocracy of Europe and to suggest that the more abundant the world's supply of gold, the poorer off we are in the humble but useful things of life. It is a nation's output of coal and iron, petroleum and copper, sulphur and lead, cement and zinc, brick and aluminum, that gives it power, rather than its output of gold and diamonds. The war-time effort to rescue platinum from its associations with luxury and idleness and draft it into the service of war industries was a tardy recognition by the public that this precious metal is also highly useful.

\section{United States Mineral Supply}

The dominance of the United States in so many of the essential minerals is proof that nature has placed us in the favored nation class. A simple comparison of the statistics of production and consumption in different countries is enough to prove that America is in the highest degree self-sufficient. ${ }^{1}$ In the five important mineral raw materials, coal, iron, copper, lead and zinc, for example, the United States in 1913 showed an aggregate exportable surplus of 24 per cent, whereas Germany's deficiencies in these same essential minerals totaled 40 per cent.

\section{Limitations to Domestic Independ- ence in Minerals}

Yet our industrial leaders cannot disregard the international viewpoint.

${ }^{1}$ Miss Eleanora F. Bliss has presented these facts and discussed their significance in the international readjustment of mineral supplies. Economic Geology, Vol. XIV, pp. 147-171, 1919. 
Abundance carries responsibility, and domestic independence may be shorterlived than we suspect. Less than a year and a half ago Professor Leith, in defining the position of the United States in regard to the international control of minerals, classified petroleum with copper as a mineral of which our exportable surplus dominates the world situation. ${ }^{2} \mathrm{He}$ regarded his own statement as necessarily somewhat tentative, but having agreed with him at that time I feel free to call attention to the strong proof now put forward by Mr. White that the United States is already dependent upon oil imports. $^{3}$ Looking forward in copper may soon become an equally evident duty.

Another reason for opening our eyes to the world view of minerals is the connection between industry and commerce. No nation, however self-sufficient, can live profitably unto itself. Even with our wealth of raw materials, there are some minerals that we can buy cheaper than we can produce them and to import the cheaper material may be good business. Of course the immediate advantage of a low price may be outweighed by the ultimate advantage of domestic independence. ${ }^{4}$ But in addition to this consideration there is that of international trade, for in commerce trade balances

${ }^{2}$ Leith, C. K., Mineral Resources of the United States, 1917, Part I, pp. 7a-16a, United States Geological Survey, 1918.

${ }^{3}$ White, David, The Petroleum Resources of the World. Seq. pp. 111-134.

${ }^{4}$ The weighing of the emergency and other factors is discussed by the author in a short paper-"Economic Limits to Domestic Independence in Minerals"-Mineral Resources of the United States, 1917, Part I, pp. 1a-6a, United Sțates Geological Survey, 1918. as well as economical freight carrying require return cargoes. To win foreign markets for our manufactured goods, our ships must bring to us the food products or the mineral raw materials from the Orient and South America.

The hunt for petroleum to meet our future needs has fortunately begun and should be prosecuted with increasing vigor. Whether oil fields thus opened upon other continents with American capital shall eventually supply crude oil to our home refineries or furnish fuel oil to American bunker stations too far distant to be economically served from our home ports, the supplies needed to develop and operate the foreign fields will come from the United States. An "International Oil" operating in South America means a market for the product of a "National Tube" operating in Pennsylvania. Such investment of American capital in the development of foreign sources will not only yield the raw material needed and afford proper returns on the investment but will create markets for American products. In these respects, it is even better than investment in foreign government bonds. Fortunately, too, transplanting the American type of mining industry in far-off, undeveloped regions is sure to raise the native standards of living, and whether or not we care to count the profits of enlightenment, each step upward calls for kerosene and sewing machines and typewriters. Fair exchange of products is good internationalism.

The future security of the industrial program must be safeguarded, then, by insuring adequacy of supply of all the essential raw materials. In the pioneer stage of our rich country, 
mineral fuels and ores have been cheap lowering manufacturing costs without -perhaps too cheap-but within the reducing wages, but wise provision for last few years, the American manu- an adequate supply of mineral raw facturer has seen these double and materials also demands attention, treble in cost to him, and the limit has even in this favored land, where the not yet been reached. The inventiveness of American engineering and the high productiveness of American skilled labor together justify the hope of bounty of nature has bred that type of optimism that thinks too little of the morrow. 